Volume 20, Nomor 2, Mei 2021, pp 159-166. Copyright (C) 2021 Jurnal
Manajemen Maranatha, Program Studi S-1 Manajemen, Fakultas Ekonomi,
Universitas Kristen Maranatha. ISSN 1411-9293 | e-ISSN 2579-4094.
https://journal.maranatha.edu/index.php/jmm

\title{
Excess cash holding, likuiditas, dan nilai perusahaan: Studi pada perusahaan non-finansial Indonesia
}

\author{
Felicia Santoso \\ Department of Management, Universitas Pelita Harapan \\ M.H. Thamrin Boulevard 1100, Klp. Dua, Kec. Klp. Dua, Tangerang, Banten 15811 \\ feliciasantoso3@gmail.com \\ Rita Juliana* \\ Department of Management, Universitas Pelita Harapan \\ M.H. Thamrin Boulevard 1100, Klp. Dua, Kec. Klp. Dua, Tangerang, Banten 15811 \\ rita.juliana@uph.edu \\ *Penulis Korespondensi
}

Submitted: Feb 27, 2021; Reviewed: Mar 08, 2021; Accepted: Mar 30, 2021

\begin{abstract}
This study aims to investigate the effect of excess cash on liquidity and firm value. The sample that is used is 211 non-financial firms listed in Indonesia Stock Exchange (IDX) with period from 2007 to 2017, resulting a total of 2321 firm-year observations. The regression model used are fixed effect and random effect model. The results show that excess cash increase trading continuity and decrease liquidity risk. This result can be caused by uninformed trader trading participation. Additionally, excess cash has a positive effect on firm value directly because with excess cash firm can invest. The study also finds that the effect of excess cash on illiquid firm value is negative, this result happened because excess cash can increase firm's information asymmetry problem. Finally, we also find that excess cash has higher effect on small size firms with financial constraint problems and higher growth opportunities.
\end{abstract}

Keywords: excess cash; firm value; liquidity risk; stock liquidity

Abstrak: Penelitian ini bertujuan untuk melihat pengaruh excess cash terhadap likuiditas dan nilai perusahaan. Sampel yang digunakan adalah 211 perusahaan non-finansial yang terdaftar pada Bursa Efek Indonesia (BEI) dengan periode tahun 2007 sampai 2017, sehingga menghasilkan 2321 observasi. Model regresi menggunakan fixed effect model dan random effect model. Hasilnya menunjukkan bahwa excess cash meningkatkan trading continuity dan mengurangi risiko likuiditas. Hasil ini terjadi karena adanya partisipasi trading dari uninformed traders. Selain itu, excess cash berpengaruh positif ke nilai perusahaan di Indonesia karena excess cash memungkinkan perusahaan untuk dapat melakukan investasi. Penelitian ini juga menemukan efek excess cash terhadap nilai perusahaan yang ilikuid adalah negatif, hal ini disebabkan karena excess cash pada perusahaan illikuid meningkatkan masalah information asymmetry. Lalu, penelitian ini juga menemukan bahwa efek excess cash terhadap likuiditas lebih besar bagi perusahaan kecil yang kesulitan finansial dan memunyai kesempatan bertumbuh yang baik.

Kata kunci: cadangan kas; likuiditas saham; nilai perusahaan; risiko likuiditas 


\section{PENDAHULUAN}

Perdebatan mengenai efek postif dan negatif excess cash masih sering dibicarakan. Penelitian ini bertujuan untuk melihat pandangan investor pada excess cash yang diobservasi melalui nilai perusahaan dan likuiditas saham perusahaan. Excess cash sendiri bermanfaat bagi perusahaan untuk berjaga-jaga apabila terjadi kekurangan di arus kas/ precautionary motive (Bates et al., 2009; Palazzo, 2012) atau sebagai sumber dana murah untuk berkembang/ cheap fund growth (Simutin, 2010). Perusahaan menganggap bahwa mengumpulkan excess cash dalam tingkat tinggi menguntungkan untuk memitigasi biaya kesulitan keuangan ketika adanya kesempatan investasi yang bagus dan sebagai cadangan ketika ekonomi sedang turun (Huang \& Mazouz, 2018). Perusahaan dengan excess cash yang tinggi memunyai rata-rata kinerja operasi yang lebih bagus (Mikkelson \& Partch, 2003). Menurut Faulkender \& Wang (2006), perusahaan yang likuid memungkinkan perusahaan untuk melakukan investasi tanpa harus menggunakan dana eksternal yang lebih mahal biayanya, sehingga bisa menghemat cost of debt, cost of equity, dan information asymmetry cost.

Motif perusahaan menyimpan kas adalah untuk berjaga-jaga apabila terjadi kekurangan dalam arus kas di masa depan, untuk transaksi operasional perusahaan, dan untuk berspekulasi mencari keuntungan. Huang \& Mazouz (2018) mengatakan dengan tingginya excess cash bisa membuat investor lebih tertarik untuk bertransaksi ketika likuiditas pasar kering karena harga saham menjadi tidak terlalu bergejolak terhadap likuiditas pasar. Alhasil, investor meningkatkan investasi dan membuat trading continuity meningkat dan membuat risiko likuiditas menurun. Penurunan dalam risiko likuiditas akan membuat cost of equity capital dan liquidity premium menurun. Excess cash bisa meningkatkan trading continuity, bergantung pada kemampuan perusahaan untuk menarik uninformed traders dengan berkurangnya cost of capital (Huang \& Mazouz, 2018). Excess cash bisa mengurangi cost of capital melalui tiga cara: (1) Melalui efisiensi dengan menggunakan pendanaan internal dengan biaya yang lebih murah dan memberikan kepastian dalam melakukan investasi (Opler et al., 1999; Bates et al., 2009), (2) Kas sebagai jaga-jaga apabila keadaan ekonomi atau arus kas memburuk, (3) Melalui penurunan liquidity premium karena meningkatnya transaksi (trading continuity). Excess cash bisa meningkatkan trading continuity (Huang \& Mazouz, 2018). Adanya excess cash akan mengurangi volatilitas dalam assets-in-place (Gopalan et al., 2012). Hal ini akan menarik lebih banyak uninformed traders. Dengan semakin banyaknya uninformed traders akan membuat inventory cost dan adverse selection cost menjadi lebih murah. Ini akan membuat transaction cost menjadi lebih murah. Dengan menurunnya transaction cost akan membuat trading continuity meningkat. Uninformed traders di sini berperan sebagai liquidity provider. Pastor \& Stambaugh (2003) juga menemukan bahwa saham yang lebih sensitif terhadap likuiditas memunyai expected return yang lebih tinggi. Huang \& Mazouz (2018) mengatakan ketika trading continuity meningkat, harga saham menjadi tidak terlalu sensitif terhadap likuiditas pasar dan lebih elastis. Dengan kata lain, excess cash juga dapat menurunkan risiko likuiditas saham perusahaan.

Ada berbagai pendapat mengenai dampak excess cash terhadap nilai perusahaan melalui information asymmetry. Jensen (1986) mengemukakan tentang implikasi free cash flow theory yang mengatakan bahwa perusahaan dengan excess cash cenderung lebih sering melakukan investasi, tapi akuisisi yang dilakukan oleh perusahaan dengan excess cash menurunkan nilai perusahaan. Kehadiran agency problem dalam perusahaan dengan excess cash bisa memerburuk nilai perusahaan. Hal ini terjadi karena adanya perbedaan kepentingan antara manajer dengan investor. Manajer ingin melakukan akuisisi dan ekspansi agar cakupan perusahaan semakin besar, sehingga mereka melakukan investasi tanpa melihat NPV proyek tersebut. Investor lebih memilih agar perusahaan melakukan pembayaran melalui dividen atau repurchase saham daripada excess cash digunakan untuk investasi projek yang tidak terlalu menguntungkan. Stulz (1990) mengatakan bahwa excess cash bisa menghancurkan nilai perusahaan dan sebaiknya excess cash harus secara optimal dijaga rendah untuk mencegah conflict of interest antara pemegang saham dengan manajer. Myers \& Majluf (1984) mengatakan bahwa information asymmetry antara manajer dan investor bisa menyebabkan underpricing terhadap sekuritas perusahaan dan membuat mahal ketika perusahaan mau mencari dana dari luar. 
Tetapi, Huang \& Mazouz (2018) menemukan dampak excess cash terhadap nilai perusahaan secara langsung adalah negatif, tetapi jika hubungan ini dilihat secara tidak langsung melalui ilikuiditas, dapat berdampak positif. Hal ini disebabkan karena nilai marjinal kas akan lebih tinggi di perusahaan yang ilikuid, memunyai kesulitan finansial, dan memunyai kesempatan bertumbuh yang banyak. Ini membuat investor mendukung untuk perusahaan ilikuid untuk memegang excess cash. Huang \& Mazouz (2018) mengatakan bahwa external fund itu mahal, sehingga perusahaan cenderung untuk lebih mengumpulkan excess cash. Dengan tingginya excess cash akan membuat information asymmetry tinggi dan membuat agency cost of cash tinggi. Sehingga, perusahaan dengan excess cash menjadi tidak menarik bagi uninformed traders. Dengan menurunnya uninformed traders akan meningkatkan kerugian yang dialami oleh market marker akibat bertransaksi dengan informed traders, sehingga membuat transaction cost semakin mahal. Ini akan membuat trading continuity menurun dan likuiditas juga menurun. Dengan menurunnya likuiditas akan membuat nilai perusahaan turun. Dan hasil penelitian Huang \& Mazouz (2018) menunjukkan bahwa efek langsung dari excess cash terhadap nilai perusahaan itu berdampak negatif, tapi efek tidak langsung excess cash melalui ilikuiditas berdampak positif terhadap nilai perusahaan, artinya investor mendukung perusahaan yang ilikuid, memunyai kesulitan finansial, dan memunyai kesempatan bertumbuh yang banyak untuk memegang excess cash. Menurut Faulkender \& Wang (2006), nilai marjinal dari kas lebih tinggi bagi perusahaan yang kesulitan kas dengan kesempatan investasi yang tinggi.

Berdasarkan penelitian-penelitian terdahulu, maka hipotesis awal penelitian ini adalah:

H1: Excess cash meningkatkan trading continuity

$\mathrm{H} 2$ : Excess cash mengurangi risiko likuiditas

H3: Excess cash memengaruhi nilai perusahaan

\section{METODE}

Penelitian ini menggunakan sampel perusahaan non-finansial yang tercatat pada Bursa Efek Indonesia. Adapun perusahaan yang tidak memiliki data yang lengkap akan dikeluarkan dari sampel penelitian. Data yang digunakan dimulai dari tahun 2007-2017, sehingga menghasilkan sampel penuh sebesar 2321 observasi. Berikut rincian pemilihan sampel:

Tabel 1. Daftar sampel perusahaan

\begin{tabular}{ll}
\hline Keterangan & Jumlah perusahaan \\
\hline $\begin{array}{l}\text { Perusahaan yang dijadikan populasi (perusahaan delist di } \\
\text { atas tahun 2017 dan perusahaan keuangan dikeluarkan) }\end{array}$ & 475 \\
Perusahaan yang IPO di atas 2007 & 220 \\
Perusahaan yang tidak lengkap datanya & 44 \\
Total perusahaan yang masuk ke dalam sampel penelitian & 211 \\
\hline
\end{tabular}

Sumber: Hasil pengolahan peneliti (2019)

Untuk menguji dampak excess cash terhadap trading continuity dan risiko likuiditas, berikut adalah regresinya (Huang \& Mazouz, 2018):

$$
\begin{aligned}
\operatorname{LIQUIDITY}_{i, t}= & \alpha+\beta_{1} \mathrm{ECASH}_{i, t}+\beta_{2} \text { MTB }_{i, t-1}+\beta_{3} \text { SIZE }_{i, t-1}+\beta_{4} \text { LEVERAGE }_{i, t-1}+ \\
& \beta_{5} D I V_{i, t-1}+\beta_{6} \text { CAPEX }_{i, t-1}+\beta_{7} R \& D_{i, t-1}+\beta_{8} \text { PRICE }_{i, t-1}+\beta_{9} R E T_{i, t-1}+\varphi_{i, t}
\end{aligned}
$$

Variabel dependen pada model 1 adalah LIQUIDITY, yaitu likuiditas perusahaan diukur dengan natural logarithm LM12 (LogLM12). LIQUIDITY merupakan variabel proxy dari trading continuity dan resiko likuiditas (Hipotesis 1 dan 2). Variabel independen utama dari penelitian ini adalah ECASH, yaitu excess cash. Untuk menguji efek dari excess cash pada likuiditas, kami memasukkan juga variabel kontrol nilai perusahaan $(M T B)$, ukuran perusahaan (SIZE), tingkat hutang (LEVERAGE), dividen (DIV), investasi (CAPEX), R\&D, harga saham perusahaan (PRICE), dan tingkat pengembalian saham (RET). Semua variabel diwinsorisasi pada level 0,01 untuk mencegah terjadinya outliers. Operasionalisasi variabel penelitian ini dapat dilihat pada Tabel 2. Penelitian ini 
juga ingin menginvestigasi dampak excess cash pada nilai perusahaan, yang mana model empirisnya adalah sebagai berikut (Huang \& Mazouz, 2018):

$$
\begin{aligned}
\text { MTB }_{i, t}= & K_{0}+K_{1} \text { ECASH }_{i, t}+K_{2} \text { LIQUIDITY }_{i, t}+K_{3} \text { ECASH }_{i, t-1} * \text { LIQUIDITY }_{i, t}+ \\
& K_{4} \text { SIZE }_{i, t-1}+K_{5} \text { TURNOVER R R }_{i, t-1}+K_{6} \text { LEVERAGE }_{i, t-1}+K_{7} \text { DIV V V V }_{i, t-1}+ \\
& K_{8} \text { CAPEX }_{i, t-1}+K_{9} \text { ROA }_{i, t-1}+v_{i, t}
\end{aligned}
$$

Variabel dependen pada model 2 adalah $M T B$, yaitu nilai perusahaan. Variabel independen utama dari penelitian ini adalah Excess cash (ECASH), likuiditas (LIQUIDITY), variabel interaksi likuiditas, dan excess cash (ECASH * LIQUIDITY). Untuk menguji efek dari ketiga independent variabel tersebut pada nilai perusahaan, kami memasukkan juga variabel kontrol, yaitu turnover saham (TURNOVER), tingkat hutang (LEVERAGE), dividen (DIV), investasi (CAPEX), dan tingkat keuntungan (ROA). Semua variabel diwinsorisasi pada level 0,01 untuk mencegah terjadinya outliers. Operasionalisasi

\begin{tabular}{|c|c|}
\hline Variabel & Operasionalisasi variabel (Huang \& Mazouz, 2018) \\
\hline LIQUIDITY & $\begin{array}{l}L M 12=\{\text { ZEROS + [(1/TURNOVER }) / D E F L A T O R]\} *(252 / T R A D) \\
(\mathrm{Liu}, 2006)\end{array}$ \\
\hline \multirow[t]{2}{*}{ ECASH } & $\begin{array}{l}\text { Excess Cash, yaitu residual dari regresi (e.g., Opler et al., 1999; Harford et al., } \\
\text { 2008; Asem \& Alam, 2014): }\end{array}$ \\
\hline & 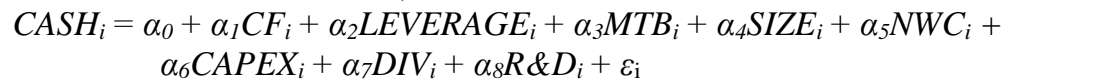 \\
\hline$M T B$ & {$[($ total liabilitas $+($ jumlah saham diterbitkan $*$ harga saham $)] /$ total aset } \\
\hline SIZE & Natural log dari (total aset - kas) \\
\hline LEVERAGE & Total debt / (total aset - kas) \\
\hline DIV & 0 artinya tidak memberikan dividen, 1 artinya memberikan dividen \\
\hline$C A P E X$ & Capital expenditure / (total aset - kas) \\
\hline$R \& D$ & Research and development expense / sales \\
\hline PRICE & Harga penutupan saham pada tahun fiskal \\
\hline TURNOVER & Jumlah saham yang ditransaksikan / jumlah saham oustanding \\
\hline ROA & Net income / total aset \\
\hline RET & Return saham \\
\hline
\end{tabular}
variabel penelitian ini dapat dilihat pada Tabel 2.

Tabel 2. Operasionalisasi variabel

Sumber: Hasil pengolahan peneliti (2019)

\section{HASIL DAN PEMBAHASAN}

Tabel 3. Deskripsi statistik full sample

\begin{tabular}{llllll}
\hline Variables & Obs & Mean & Std. Dev & Min & Max \\
\hline Liquidity & 2,321 & 1,30473 & 0,813895 & 0,0087056 & 2,401684 \\
ECASH & 2,321 & 0,0634157 & 0,0185728 & $-0,0322261$ & 0,181406 \\
MTB & 2,321 & 1,733859 & 2,446277 & 0,326897 & 19,25773 \\
SIZE & 2,321 & 9,244648 & 0,7564297 & 7,468596 & 10,91516 \\
LEVERAGE & 2,321 & 0,290676 & 0,3381735 & 0 & 2,539371 \\
DIV (dummy) & 2,321 & 0,4915984 & 0,5000371 & 0 & 1 \\
CAPEX & 2,321 & 0,0546335 & 0,0603518 & 0 & 0,3115984 \\
R\&D & 2,321 & 0,0003456 & 0,0021904 & 0 & 0,0188894 \\
PRICE & 2,321 & 1557,753 & 3376,479 & 39,42 & 22298,6 \\
RET & 2,321 & 0,2773596 & 0,8552806 & $-0,7857143$ & 4,73913 \\
TURNOVER & 2,321 & 0,5296208 & 1,154004 & 0,0000166 & 8,006233 \\
ROA & 2,321 & 0,0348718 & 0,1301652 & $-0,6845998$ & 0,4066949 \\
\hline Sumber: Hasi
\end{tabular}

Sumber: Hasil pengolahan peneliti sendiri (2019)

Tabel 4. Deskripsi statistik sub-sampel perusahaan besar-kecil berdasarkan total aset

\begin{tabular}{lllllllllll}
\hline \multirow{2}{*}{ Variables } & Obs & \multicolumn{3}{c}{ Mean } & \multicolumn{3}{c}{ Std Dev } & Min & Max \\
& Besar & Kecil & Besar & Kecil & Besar & Kecil & Besar & Kecil & Besar & Kecil \\
\hline Liquidity & 1,161 & 1,160 & 0,955 & 1,653 & 0,777 & 0,690 & 0,006 & 0,0087 & 2,389 & 2,406 \\
162 & & & & & & & & & &
\end{tabular}




\begin{tabular}{lllllllllll} 
ECASH & 1,161 & 1,160 & 0,063 & 0,063 & 0,016 & 0,020 & $-0,008$ & $-0,3222$ & 0,170 & 0,181 \\
MTB & 1,161 & 1,160 & 1,751 & 1,827 & 1,884 & 3,734 & 0,411 & 0,255 & 13,369 & 29,925 \\
SIZE & 1,161 & 1,160 & 9,861 & 8,625 & 0,455 & 0,444 & 9,214 & 7,177 & 11,097 & 9,2212 \\
LEVERAGE & 1,161 & 1,160 & 0,290 & 0,340 & 0,222 & 0,799 & 0 & 0 & 1,112 & 7,173 \\
DIV & 1,161 & 1,160 & 0,639 & 0,343 & 0,480 & 0,474 & 0 & 0 & 1 \\
CAPEX & 1,161 & 1,160 & 0,062 & 0,0469 & 0,057 & 0,061 & 0,0002 & 0 & 0,299 & 0,322 \\
R\&D & 1,161 & 1,160 & 0,0006 & 0,0001 & 0,003 & 0,0006 & 0 & 0 & 0,028 & 0,0056 \\
PRICE & 1,161 & 1,160 & 2741,19 & 522,089 & 5253,68 & 1063,89 & 50 & 25 & 35400 & 7600 \\
RET & 1,161 & 1,160 & 0,251 & 0,326 & 0,8037 & 1,029 & $-0,808$ & $-0,748$ & 4,172 & 6,955 \\
ROA & 1,161 & 1,160 & 0,054 & 0,011 & 0,103 & 0,176 & $-0,313$ & $-1,119$ & 0,406 & 0,411 \\
TURNOVER & 1,161 & 1,160 & 0,504 & 0,594 & 0,909 & 1,639 & 0,00002 & 0,00002 & 5,288 & 12,147 \\
\hline
\end{tabular}

Sumber: Hasil pengolahan peneliti sendiri (2019)

Tabel 5. Deskripsi statistik sub-sampel perusahaan besar kecil berdasarkan market value equity

\begin{tabular}{|c|c|c|c|c|c|c|c|c|c|c|}
\hline \multirow[t]{2}{*}{ Variables } & \multicolumn{2}{|l|}{ Obs } & \multicolumn{2}{|l|}{ Mean } & \multicolumn{2}{|l|}{ Std. Dev } & \multicolumn{2}{|l|}{ Min } & \multicolumn{2}{|l|}{$\operatorname{Max}$} \\
\hline & Besar & Kecil & Besar & Kecil & Besar & Kecil & Besar & Kecil & Besar & Kecil \\
\hline Liquidity & 1,161 & 1,160 & 0,975 & 1,634 & 0,798 & 0,686 & 0,006 & 0,008 & 2,393 & 2,406 \\
\hline$E C A S H$ & 1,161 & 1,160 & 0,064 & 0,062 & 0,017 & 0,0199 & $-0,009$ & $-0,032$ & 0,172 & 0,181 \\
\hline$M T B$ & 1,161 & 1,160 & 2,211 & 1,298 & 2,653 & 2,496 & 0,570 & 0,255 & 18,84 & 23,549 \\
\hline SIZE & 1,161 & 1,160 & 9,777 & 8,709 & 0,550 & 0,5395 & 8,542 & 7,177 & 11,097 & 9,980 \\
\hline LEVERAGE & 1,161 & 1,160 & 0,2505 & 0,330 & 0,210 & 0,448 & 0 & 0 & 0,987 & 3,217 \\
\hline$D I V$ & 1,161 & 1,160 & 0,678 & 0,304 & 0,467 & 0,460 & 0 & 0 & 0 & 1 \\
\hline CAPEX & 1,161 & 1,160 & 0,066 & 0,042 & 0,060 & 0,057 & 0,0002 & 0 & 0,307 & 0,322 \\
\hline$R \& D$ & 1,161 & 1,160 & 0,0006 & 0,00009 & 0,003 & 0,0005 & 0 & 0 & 0,028 & 0,0048 \\
\hline PRICE & 1,161 & 1,160 & 2941,05 & 325,51 & 5271,05 & 379,25 & 50 & 25 & 35400 & 2100 \\
\hline$R E T$ & 1,161 & 1,160 & 0,273 & 0,291 & 0,829 & 0,933 & $-0,807$ & $-0,75$ & 4,56 & 5,7272 \\
\hline TURNOVER & 1,161 & 1,160 & 0,532 & 0,560 & 0,997 & 1,5433 & 0,00001 & 0,0002 & 5,875 & 12,0775 \\
\hline$R O A$ & 1,161 & 1,160 & 0,067 & 0,0013 & 0,109 & 0,147 & $-0,337$ & $-0,891$ & 0,418 & 0,392 \\
\hline
\end{tabular}

Sumber: Hasil pengolahan peneliti sendiri (2019)

Tabel 3 menjelaskan karakteristik data sampel penuh. Tabel 4 menjelaskan karakteristik data subsampel untuk perusahaan besar-kecil berdasarkan total aset. Tabel 5 menjelaskan karakteristik data sub-sampel untuk perusahaan besar-kecil berdasarkan market value equity. Dari Tabel 3, bisa didapatkan bahwa Liquidity memunyai rerata 1,304 dengan nilai minimum 0,0087 dan nilai maksimum 2,402, semakin besar Liquidity menunjukkan trading continuity yang lebih rendah dan risiko likuiditas yang lebih tinggi. $E C A S H$ didapat dari residual persamaan (2) dengan rata-rata 0,0634 dengan nilai minimum $-0,032$ dan nilai maksimum 0,1814. ECASH yang positif (negatif) menunjukkan perusahaan menyimpan kas berlebih lebih banyak (lebih sedikit) dari yang seharusnya perusahaan butuhkan untuk operasional dan investasi perusahaan. Kemudian, peneliti membagi sampel penuh menjadi perusahaan besar kecil berdasarkan total aset dan market value equity. Sampel penuh diurutkan dari terbesar sampai terkecil berdasarkan total aset dan market value equity, lalu diambil data tengah atau median. Data yang berada di atas data tengah termasuk perusahaan besar dan yang di bawah data tengah termasuk perusahaan kecil. Dari Tabel 4 dan Tabel 5, bisa didapatkan bahwa perusahaan besar baik berdasarkan total aset dan market value equity memunyai risiko likuiditas yang lebih rendah dan excess cash lebih banyak. Perusahaan besar memunyai SIZE, CAPEX, $R \& D$, dan $R O A$ yang lebih besar dan membayar dividen lebih sering daripada perusahaan kecil. Perusahaan kecil memunyai LEVERAGE dan TURNOVER yang lebih besar dan memberikan RETURN yang lebih tinggi.

Tabel 6. Hasil regresi efek excess cash terhadap risiko likuiditas (panel data regression model)

\begin{tabular}{|c|c|c|c|c|c|}
\hline \multirow{2}{*}{$\begin{array}{l}\text { Variabel } \\
\text { Independen }\end{array}$} & \multicolumn{5}{|c|}{ Variabel Dependen: Liquidity } \\
\hline & Full Sample & Besar (Tot Asset) & Kecil (Tot Asset) & $\begin{array}{l}\text { Besar (MV } \\
\text { Equity) }\end{array}$ & $\begin{array}{l}\text { Kecil ( } M V \\
\text { Equity) }\end{array}$ \\
\hline$E C A S H$ & $-1,843 * * *$ & $-0,884 *$ & $-3,853 * * *$ & $-2,173 * * *$ & $-2,409 * * *$ \\
\hline MTB & $-0,0542 * * *$ & $-0,072 * * *$ & $-0,0521 * * *$ & $-0,031 * *$ & $-0,020 * * *$ \\
\hline SIZE & $-0,8025 * * *$ & $-0,754 * * *$ & $-0,948 * * *$ & $-0,810^{* * *}$ & $-0,335^{* * *}$ \\
\hline LEVERAGE & $0,4209^{* * *}$ & $0,699 * * *$ & $0,222 * * *$ & $0,824 * * *$ & $0,096 * * *$ \\
\hline$D I V$ & $-0,1460 * * *$ & $-0,211 * * *$ & $-0,0269$ & $-0,123 * * *$ & 0,010 \\
\hline CAPEX & $-0,5500 * * *$ & $-0,0907$ & $-0,5209 * * *$ & $-0,556^{* * *}$ & $-0,315^{* * *}$ \\
\hline$R \& D$ & $-5,7409$ & 4,113 & $-132,95 * * *$ & $8,312 * * *$ & 5,840 \\
\hline PRICE & $-0,000016^{* * *}$ & $-8,17 \mathrm{e}-06^{* * *}$ & 0,000015 & $-0,00001^{* * *}$ & $0,00026^{* * *}$ \\
\hline$R E T$ & $-0,00059$ & 0,0167 & $-0,0123$ & 0,030 & $-0,0527 * * *$ \\
\hline
\end{tabular}


Jurnal Manajemen Maranatha ø Vol. 20 Nomor 2, Mei (2021)

\begin{tabular}{llllll}
$R^{2}$ (prob chi) & 0,2160 & 0,2194 & 0,1523 & 0,2175 & 0,000 \\
Cons & $8,941^{* * *}$ & $8,517 * * *$ & $10,174 * * *$ & $9,020^{* * *}$ & $4,704 * * *$ \\
\hline Observations & 2,321 & 1,161 & 1,160 & 1,161 & 1,160 \\
\hline
\end{tabular}

Sumber: Hasil pengolahan peneliti sendiri (2019)

*Signifikasi pada tingkat $10 \%$

**Signifikansi pada tingkat $5 \%$

***Signifikansi pada tingkat $1 \%$

Tabel 6 kolom 1 menjelaskan pengaruh excess cash terhadap trading continuity dan risiko likuiditas pada full sampel. Pengaruh ECASH terhadap Liquidity adalah negatif dan signifikan sebesar -1,843. Artinya, setiap excess cash naik, maka variabel Liquidity akan turun. Semakin kecil variabel Liquidity menunjukkan trading continuity semakin tinggi dan risiko likuiditas semakin rendah. Hasil ini menjadi pembuktian atas hipotesis 1 dan 2 penelitian ini. Excess cash bisa meningkatkan trading continuity bergantung pada kemampuan perusahaan untuk menarik uninformed traders dengan berkurangnya cost of capital (Huang \& Mazouz, 2018). Excess cash bisa mengurangi cost of capital melalui tiga cara: (1) Melalui efisiensi dengan menggunakan pendanaan internal dengan biaya yang lebih murah dan memberikan kepastian dalam melakukan investasi (Opler et al., 1999; Bates et al., 2009), (2) Kas sebagai jaga-jaga apabila keadaan ekonomi atau arus kas memburuk, (3) Melalui penurunan transaction cost karena meningkatnya transaksi (trading continuity). Adanya excess cash akan mengurangi volatilitas dalam assets-in-place (Gopalan et al., 2012). Hal ini akan menarik lebih banyak uninformed traders. Dengan semakin banyaknya uninformed traders akan membuat inventory cost dan adverse selection cost menjadi lebih murah, sehingga transaction cost akan menjadi lebih murah. Ini akan membuat trading continuity meningkat. Dengan meningkatnya trading continuity, harga saham menjadi tidak terlalu sensitif terhadap likuiditas pasar dan risiko likuiditas menurun.

Lalu untuk variabel kontrol pada Tabel 6 untuk kolom 1 menunjukkan bahwa MTB, SIZE, dan CAPEX memunyai pengaruh negatif signifikan terhadap Liquidity. Artinya, ketika MTB, SIZE, dan CAPEX naik, maka trading continuity akan meningkat dan risiko likuiditas akan menurun. MTB, SIZE, dan CAPEX sendiri adalah patokan growth opportunities. LEVERAGE berpengaruh positif terhadap Liquidity, artinya ketika hutang perusahaan bertambah, maka trading continuity akan menurun dan risiko likuiditas akan meningkat. DIV dan RET memunyai pengaruh negatif signifikan terhadap Liquidity. Artinya, ketika perusahaan semakin sering membagikan dividen dan return saham yang sebelumnya menguntungkan, maka investor akan semakin sering mentransaksikan saham tersebut. Ini akan membuat trading continuity meningkat dan risiko likuiditas menurun. $R \& D$ memunyai pengaruh negatif tidak signifikan terhadap Liquidity. Hal ini bisa disebabkan karena banyak perusahaan di Indonesia yang tidak melakukan $R \& D$. PRICE memunyai pengaruh positif signifikan terhadap Liquidity. Artinya, ketika harga saham semakin mahal, maka trading continuity akan meningkat dan risiko likuiditas menurun. Hal ini bisa disebabkan karena penyampaian informasi yang dilakukan secara tidak serentak atau sekuensial (Karpoff, 1987).

Lalu dari Tabel 6 kolom 2-4 bisa didapatkan bahwa efek excess cash terhadap Liquidity lebih besar bagi perusahaan kecil, baik berdasarkan total aset ataupun market value equity. Efek excess cash akan lebih berguna bagi perusahaan kecil yang kesulitan finansial dan memunyai kesempatan investasi yang baik. Ini terjadi karena investor berpikir bahwa perusahaan kecil akan berkembang lebih besar dan memberikan return yang lebih tinggi, sehingga investor mau melakukan transaksi saham terhadap perusahaan kecil dan membuat risiko likuiditasnya turun. Hal ini sesuai dengan penelitian Huang \& Mazouz (2018) yang mengatakan bahwa keuntungan dari excess cash lebih besar bagi perusahaan kecil dengan kesempatan bertumbuh yang baik (Opler et al., 1999; Bates et al., 2009).

Tabel 7. Hasil regresi efek excess cash, risiko likuiditas, dan excess cash melalui risiko likuiditas terhadap nilai perusahaan (panel data regression model)

\begin{tabular}{ll}
\hline Variabel Independent & Variabel Dependent: Q \\
\cline { 2 - 2 } & Full Sample \\
\hline ECASH & $16,894 * * *$ \\
Liquidity & $-0,167 * * *$ \\
ECASH $*$ Liquidity & $-4,421 * * *$
\end{tabular}




$\begin{array}{ll}\text { SIZE } & -0,898^{* * *} * \\ \text { TURNOVER } & 0,0036 \\ \text { LEVERAGE } & 0,357 \\ \text { DIV } & -0,066 \\ \text { CAPEX } & -0,508 \\ \text { ROA } & -0,949 \\ \text { Cons } & 9,614 * * * \\ R^{2} & 0,0526\end{array}$

Sumber: Hasil pengolahan peneliti sendiri (2019)

*Signifikasi pada tingkat $10 \%$

**Signifikansi pada tingkat $5 \%$

$* * *$ Signifikansi pada tingkat $1 \%$

Tabel 7 menjelaskan pengaruh excess cash dan risiko likuiditas terhadap nilai perusahaan. Hasil koefisien ECASH menunjukkan bahwa Excess cash mempunyai pengaruh positif signifikan terhadap nilai perusahaan, hasil ini menjadi pembuktian atas hipostesis 3 penelitian ini. Hal ini terjadi karena dengan adanya internal kas yang lebih murah membuat perusahaan bisa memanfaatkan kesempatan bisnis yang ada dan memberikan kepastian tentang pendanaan dan implementasi untuk rencana investasi di masa depan (Opler et al., 1999; Bates et al., 2009). Simutin (2010) mengatakan kas bisa digunakan sebagai sumber dana murah untuk berkembang (cheap fund growth). Dengan adanya excess cash, perusahaan bisa melakukan speculation motive, yaitu melakukan investasi dan mengambil keuntungan dengan dana yang lebih murah, yaitu excess cash. Dengan melakukan investasi yang menguntungkan dengan excess cash, maka perusahaan bisa meningkatkan nilai perusahaan. Lalu, Liquidity memunyai pengaruh negatif signifikan terhadap nilai perusahaan. Artinya, ketika perusahaan semakin ilikuid, maka nilai perusahaan akan turun. Hal ini terjadi karena performa perusahaan yang ikut turun seiring dengan semakin ilikuidnya perusahaan. Lalu, pengaruh excess cash melalui Liquidity terhadap nilai perusahaan adalah negatif signifikan. Hal ini terjadi karena excess cash bisa menghancurkan nilai perusahaan yang ilikuid kalau adanya information asymmetry (Harford et al., 2008; Stulz, 1990; Myers \& Majluf, 1984; Jensen, 1986). Information asymmetry dan agency conflict membuat manajer lebih menggunakan excess cash untuk menguntungkan dirinya sendiri daripada menguntungkan pemegang saham. Manajer akan melakukan akuisisi dan investasi yang merugikan dengan excess cash yang ada. Dengan keadaan yang mana perusahaan memunyai information asymmetry yang tinggi, lalu ditambah dengan keadaan ilikuiditas perusahaan yang naik, maka hal ini akan membuat nilai perusahaan menurun.

\section{SIMPULAN DAN SARAN}

Penelitian ini bertujuan untuk melihat efek excess cash terhadap likuiditas dan nilai perusahaan yang terdapat di Indonesia. Hasil penelitian ini menemukan bahwa efek excess cash terhadap likuiditas adalah negatif signifikan. Ketika excess cash naik, mengakibatkan trading continuity dan likuiditas naik. Hal ini terjadi karena adanya partisipasi trading dari unimformed traders yang mengurangi transaction cost. Ini akan membuat trading continuity naik dan likuiditas naik.

Selain itu, penelitian ini juga menemukan bahwa efek excess cash terhadap nilai perusahaan adalah positif signifikan. Ketika excess cash naik, maka nilai perusahaan akan naik. Excess cash bisa meningkatkan nilai perusahaan, karena internal kas yang lebih murah membuat perusahaan bisa memanfaatkan kesempatan bisnis yang ada dan memberikan kepastian tentang pendanaan dan implementasi untuk rencana investasi di masa depan. Pada sisi lain, efek excess cash dalam perusahaan yang ilikuid terhadap nilai perusahaan adalah negatif signifikan. Artinya, ketika excess cash dan Liquidity naik, maka nilai perusahaan akan turun. Hal ini terjadi karena adanya information asymmetry antara manajer dan pemegang saham. Ketika perusahaan memiliki excess cash, manajer cenderung lebih memilih untuk melakukan investasi, seperti akuisisi dan memerluas cakupan manajer dan tidak mau membayar dividen. Dan sering kali, investasi yang dilakukan manajer tidak memberikan untung yang banyak dan bahkan menghancurkan nilai perusahaan (Harford et al., 2008). 
Terakhir, kami juga menemukan bahwa efek excess cash terhadap perusahaan kecil lebih besar daripada terhadap perusahaan besar. Excess cash lebih berharga bagi perusahaan kecil yang kesulitan finansial dan memunyai kesempatan bertumbuh yang baik (Opler et al., 1999; Bates et al., 2009, Huang \& Mazouz, 2018).

\section{REFERENSI}

Asem, E. \& Alam, S. (2014). Cash hoards and changes in investors' outlook. Journal of Financial Research, 37(1), 119-137. https://doi.org/10.1111/jfir.12031

Bates, T. W., Kahle, K. M., \& Stulz, R. M. (2009). Why do US firms hold so much more cash than they used to? The Journal of Finance, 64(5), 1985-2021. https://doi.org/10.1111/j.15406261.2009.01492.x

Faulkender, M. \& Wang, R. (2006). Corporate financial policy and the value of cash. The Journal of Finance, 61(4), 1957-1990. https://doi.org/10.1111/j.1540-6261.2006.00894.x

Gopalan, R., Kadan, O., \& Pevzner, M. (2012). Asset liquidity and stock liquidity. Journal of Financial and Quantitative Analysis, 47(2), 333-364. https://doi.org/10.1017/S0022109012000130

Harford, J., Mansi, S. A., \& Maxwell, W. F. (2008). Corporate governance and firm cash holdings in the US. Journal of Financial Economics, 87(3), 535-555. https://doi.org/10.1016/j.jfineco.2007.04.002

Huang, W. \& Mazouz, K. (2018). Excess cash, trading continuity, and liquidity risk. Journal of Corporate Finance, 48, 275-29. https://doi.org/10.1016/j.jcorpfin.2017.11.005

Jensen, M. C. (1986). Agency costs of free cash flow, corporate finance, and takeovers. The American Economic Review, 76(2), 323-329. http://papers.ssrn.com/abstract=99580.

Karpoff, J. M. (1987). The relation between price changes and trading volume: A survey. Journal of Financial and Quantitative Analysis, 22(1), 109-126. https://doi.org/10.2307/2330874

Liu, W. (2006). A liquidity-augmented capital asset pricing model. Journal of Financial Economics, 82(3), 631-671. https://doi.org/10.1016/j.jfineco.2005.10.001

Mikkelson, W. H. \& Partch, M. M. (2003). Do persistent large cash reserves hinder performance? Journal of Financial and Quantitative Analysis, 38(2), 275-294. https://doi.org/10.2307/4126751

Myers, S. C. \& Majluf, N. S. (1984). Corporate financing and investment decisions when firms have information that investors do not have. Journal of Financial Economics, 13(2), 187-221. https://doi.org/10.1016/0304-405X(84)90023-0

Opler, T., Pinkowitz, L., Stulz, R., \& Williamson, R. (1999). The determinants and implications of corporate cash holdings. Journal of Financial Economics, 52(1), 3-46. https://doi.org/10.1016/S0304-405X(99)00003-3.

Palazzo, B. (2012). Cash holdings, risk, and expected returns. Journal of Financial Economics, 104(1), 162-185. https://doi.org/10.1016/j.jfineco.2011.12.009

Pastor, L. \& Stambaugh, R. F. (2003). Liquidity risk and expected stock returns. Journal of Political Economy, 111(3), 642-685. https://doi.org/10.1086/374184.

Simutin, M. (2010). Excess cash and stock returns. Financial Management, 39(3), 1197-1222. https://doi.org/10.1111/j.1755-053X.2010.01109.x

Stulz, R. (1990). Managerial discretion and optimal financing policies. Journal of financial Economics, 26(1), 3-27. https://doi.org/10.1016/0304-405X(90)90011-N. 